\title{
Un adieu imprévu!
}

Eu vejo o seu caderno de receitas. Receitas de culinária. Na contra capa, vejo os números de telefone das pessoas mais próximas a você e vejo o endereço delas também. Penso que você queria mandar cartas para elas ou ir visitá-las. Je ne sais pas. O seu caderninho está cheio de receitas; desde o seu bolo de cenoura, até sua receita de pães caseiros que só você sabia fazer. Lembro-me de ter ajudado na confecção de uma de suas receitas. J'étais petite, mas quando te ajudava me sentia une grande chef de cuisine. Lembro de uma vez que você me pediu para ir correndo buscar esse caderno de receitas, enquanto passava uma receita inédita na TV, que você queria fazer après. Os anos foram passando e a tradição da execução das receitas, ensemble, foi virando hábito, até que o tempo a tout effacé.

Então, você se foi...

Não me lembro de como tudo aquilo aconteceu. Foi tudo tão rápido. Lembro-me apenas do seu rosto adormecido, e foi assim que te vi, dormindo estava e dormindo você se foi. Hoje o que sei é que o seu caderno de receitas continua aqui e tento reproduzir cada uma de suas receitas em tentativas frustradas. Não é a mesma coisa! Falta o seu toque especial. Eu hoje continuo a escrever receitas, mas não receitas de culinária, e sim receitas de como encarar a vida que nos toma pessoas tão especiais e importantes como você.

Lembro-me das suas últimas palavras para comigo: "Bonne nuit, chérie" e apagou la lumière.

\footnotetext{
${ }^{1}$ Estudante da graduação em Letras- Língua Portuguesa e Língua Francesa pela Universidade Federal de Campina Grande. E-mail: deborah.alves79@gmail.com
} 